\title{
The influence of microgrooved surfaces on the behavior and celluar function of osteoblasts
}

\author{
Qirong Li, Yuchen Guo and Yongyue Wang* \\ West China School of Stomatology Sichuan University, oral implantology, Chengdu, Sichuan 610041, China
}

\begin{abstract}
Since 1945 Weiss Paul described the phenomenon 'contact guidance' which means the cell elongates along the direction of the groove and migrates guided by the grooves. Cell could sense the surface topography where it lies and react to these surface cues. Many researches have devoted themselves to reveal the potential mechanisms. The interaction is mainly mediated by the cytoskeleton, the focal adhesions and the extracellular matrix (ECM). But how would the groove dimensions affect the cellular behavior is still obscure. Nowadays, micro fabrication techniques such as electron beam lithography have been applied to the production of microtextured surfaces. They are relatively fast and cheap, and could fabricate microgrooves of reasonable size. Thus, they have been widely utilized to generate (micro-) nano-topographical surfaces or scaffolds for in vitro cell research. According to the report of P. CLARK, the response of cells to micro-grooved surfaces is cell typedependent, so the focus of this review is on the osteoblast(s) reaction to micro-grooved surfaces.
\end{abstract}

\section{Introduction}

A century ago, in 1911 Harrison depicted that cells cultured on spider's webs grew along the fibers [1]. Later on, in 1945 Weiss $\mathrm{P}$ initially named the phenomenon 'contact guidance': a tendency of cells to align, grow, or migrate along the grooves [2]. Cell can 'sense' the surface topography and then take reaction to these surface cues. The interaction between substrates and cells is achieved through the effort of the cytoskeleton, the extracellular matrix (ECM) [3-5] and the focal adhesions [6].

In terms of the defined (micro-) nano-topographical surface, they are usually produced by the micromachining technology: lithographic patterning (photolithography, electron beam lithography, colloidal lithography), galvanoformung abformung process LIGA, focused ion beam-chemical vapor deposition FIB-CVD and so on. Some of these techniques such as electron beam lithography (EBL) have been developed for creating well-defined patterns with feature sizes $<10 \mathrm{~nm}$ [7]. Recent years, femtosecond laser patterning has obtained a position in the microgrooves ' machining [8,9]. These techniques promoted the development of biomaterials and tissue engineering greatly.

As the response of cells to micro-grooved surfaces is cell typedependent [10], the react of osteoblasts to the micro-machined surface might be different from other cell types. This review is based on the gathered information about the defined microgrooves, ranging from nanometers to microns, role on the osteoblasts, aiming at finding out the interaction between these ultrafine arrays and the bone-forming cells.

\section{Micro/Nanofabrication technologies}

A variety of methods such as Femtosecond laser microtexturing can be applied to the fabrication of microtextured surface. These nano/ micro patterning techniques were early used in the semiconductor and microelectronics industries [11], later they were increasingly applied in biology, medicine, and biomedical engineering fields [12]. Researchers
$[13,14]$ use these techniques to manufacture materials, attempting to get a value that is optimal for the growth of cells. These technologies both have their adaptations as well as limitations, also they have got developments. Hence it is hard to define the best tech in this field [15].

\section{Microgrooved surface influences cellular behavior}

Cell adhesive to the grafting materials, more importantly, they are in reciprocity with them. Different surface materials and topographies may induce distinct cell morphology, proliferation, and gene expression [16]. Cells can "sense" substrate elasticity $[17,18]$ as long as its surface patterns in the scope of $10 \mathrm{~nm}$ to $100 \mathrm{~mm}[19,20]$.

Different dimensions are thought to play varied roles in cellular behavior $[10,21]$. The average size of the osteoblasts is $20-30 \mu \mathrm{m}$. When the dimensions of grooves/ridges are reduced to the sizes of the cells and less, topographic effects on cell orientation become more prominent [22]. As will be discussed below, a majority of results focused on groove width of the micro-or-nanoscaled surface, some reports show that ridge width is more important in conducting the cellular behavior, while maybe the groove depth is the leading factor inducing cellular activities.

Groove/ridge topographies are important modulators of both cellular adhesion and osteospecific function and that groove width is vital in determining cellular response [23]. Certain groove width guides the cell to align along the direction $[8,9,24,25]$. The change of the

Correspondence to: Yongyue Wang, DDS, Ph.D, Professor, Department of Oral Implantology, West China Hospital of Stomatology, Sichuan University, \#14, 3rd Section, Renmin Nan Road Chengdu, Sichuan 610041, China, Tel.:86-2885503579; Fax: 86-28-85582167; E-mail: westchinawangyy@163.com

Key words: osteoblast(s), nanotechnology, surface chemistry/properties, cell biology, cell differentiation, cell-matrix interactions

Received: August 29, 2016; Accepted: September 19, 2016; Published: September 22, 2016 
width affects celluar shape [26], attachment [27], cellular proliferation [28] as well as bone forming ability $[25,26]$. Form these opinions and Table 1 and 2, we can infer that substrates with the microgroove width of $1-5 \mu \mathrm{m}$, particularly $2 \mu \mathrm{m}$ seems to be optical for the biological behavior of osteoblasts. On $2 \mu \mathrm{m}$-wide-grooves the cellular adhesion [29], proliferation [28], osteogenic differentiation [28,30] as well as calcification [28]. Also, these nanophase material increased adhesions of osteoblasts compared with the conventional materials [31]. Depicted in table 2, almost all of these dimensions guide the cells to align along the long axis of micropatterns. Some nano-dimensions display an osteogenic influencing function $[25,30,32]$.

Those who focused on the effect of ridge part had some limited findings. Alexey Klymov et al. designed the substrates with ridge to groove ratios of 1:1, 1:3 and 3:1. He demonstrated that nano-grooved patterns with the ridge to groove ratio of 1:3 showed cell repelling, meanwhile grooves with the ridge to groove ratio of 3:1 partially showed cell attraction during cellular selective migration [33]. Apart from that the ridge width clearly enhanced differentiation of MSCs towards specific lineages [30]. Tests on other kinds of cells, say fibroblasts, found that ridge width is the main parameter affecting cell alignment (alignment being inversely proportional to ridge width) [34].

Actually there is no defined item about the influence of groove depth on the osteoblast. From the information Azeem A reported, $306 \mathrm{~nm}$ and $2046 \mathrm{~nm}$ promoted osteoblasts alignment parallel to underlined topography. Besides this size showed its osteogenesis ability [32]. Kenichi Matsuzaka observed that on a $0.5 \mu \mathrm{m}$ deep and $10 \mu \mathrm{m}$ wide grooved surface, the cell descends into the groove, on a $1.5 \mu \mathrm{m}$ deep and $1 \mu \mathrm{m}$ wide grooved surface, cells attach to the ridges only. Nowhere, differences were observed between specimens with different groove depths. Instead Kenichi Matsuzaka attributed this phenomenon to the width of the ridge merely [27].

In vivo studies on effect of the surface micromachining to the osseointegration also take for the positive side. The laser micromachining technology enhances bone [24] and soft-tissue integration and controls the local microstructural geometry of attached bone [35]. The organized pattern of the microgrooved surfaces is capable of resulting in transverse collagen fiber microenvironment reaction to the load, being positive to promote and to maintain the bone remodeling; in addition, blood vessels and bone cells are able to penetrate microgrooved surfaces [36]. What's more, micromachined implants enhances primary and secondary implant stability, preserves crestal bone levels [36,37].

\section{Conclusions and outlook}

With the acceptance of 'contact guidance' theory, many defined patterns were made by various micro/nano technoloies, prompting the study of different dimensions to the cellular behavior. The limited collected data in the table 1 and 2 showed that the groove width is the most influencing factor affecting the osteoblasts. On the micropatterned substrates, osteoblasts adhere and elongate along the long axis of the microgrooves. Improper width of microgrooves may lead to adhesion down growth. On certain groove width cell density, proliferation and osteogenic ability show an improvement. The differentiation also can be affected by the nanotopography. However, the reports based on the virtues of the ridge width and the depth of the array still needs further exploration. Moreover, we can do a further step research on the effect

Table 1. The influence of microscale microgrooves on osteoblasts' function.

\begin{tabular}{|c|c|c|c|c|c|}
\hline References & Cell and Substrate type & Groov width $(\mu \mathrm{m})$ & $\begin{array}{l}\text { Ridge width } \\
(\mu \mathrm{m})\end{array}$ & $\begin{array}{l}\text { Groove Depth } \\
(\mu \mathrm{m})\end{array}$ & Results \\
\hline $\begin{array}{l}\text { Delgado-Ruíz et al. } \\
\text { 2015) [9] }\end{array}$ & hFOB, zirconia & 30 & 70 & - & LSA, density and cellular activity increase \\
\hline $\begin{array}{l}\text { (Matsuzaka et al. } \\
\text { 2003) [27] }\end{array}$ & RBM cells, polystyrene & $1,2,5,10$ & $1,2,5,10$ & $0.5,1,1.5$ & $\begin{array}{l}\text { smooth and grooves }>5 \mu \mathrm{m} \text { cells extensions close to substrates grooves } 2 \mu \mathrm{m} \\
\text { were bridged }\end{array}$ \\
\hline $\begin{array}{l}\text { (Puckett } \text { et al. } \\
\text { 2008) [26] }\end{array}$ & $\begin{array}{l}\text { human osteobalsts, } \\
\text { titanium }\end{array}$ & $80,48,22$ & 45,3530 & - & Attachment gradually decrease, cellular function increase, cellular shape change \\
\hline $\begin{array}{l}\text { (Biggs et al. } \\
\text { 2009) [39] }\end{array}$ & HOB, PMMA & 10,100 & 10,100 & $300 \mathrm{~nm}$ & $\begin{array}{l}10 \mu \mathrm{m} \text { focal adhesions and osteospecific lineage decrease adipospecific genes } \\
\text { increased } 100 \mu \mathrm{m} \text { cellular adhesion increase }\end{array}$ \\
\hline $\begin{array}{l}\text { (Ismail et al. } \\
\text { 2007) [29] }\end{array}$ & MG63, silicon & $2,4,8,10$ & $1.5-2$ & $\begin{array}{l}\text { cell viability } 8, \\
10 \mu \mathrm{m} \text { grooves } \\
\text { increase }\end{array}$ & smaller groove sizes smooth one's better cell adhesion \\
\hline $\begin{array}{l}\text { (Abagnale } \text { et al. } \\
\text { 2015) [30] }\end{array}$ & MSCs, Polyimide & $2,3,5,10,15$ & $2,3,5,10,15$ & $\begin{array}{l}15 \text { down to sub- } \\
\text { micrometer }\end{array}$ & $\begin{array}{l}15 \mu \mathrm{m} \text { ridges increased, adipogenic differentiation, } 2 \mu \mathrm{m} \text { enhanced osteogenic } \\
\text { differentiation }\end{array}$ \\
\hline $\begin{array}{l}\text { (Biggs et al. } \\
2008)[23]\end{array}$ & HOBs, Silicon & $10,25,100$ & $10,25,100$ & $330 \mathrm{~nm}$ & $\begin{array}{l}\text { planar adhesion more, } 100 \mu \mathrm{m} \text { increased osteospecific function, } 25 \mu \mathrm{m} \text { reduction } \\
\text { SMA increase FX formation, } 10 \mu \mathrm{m} \text { reduced, adhesion and induced an interplay } \\
\text { of up- a and downregulation of gene expression }\end{array}$ \\
\hline $\begin{array}{l}\text { (Taniguchi et al. } \\
\text { 2015) [28] }\end{array}$ & $\begin{array}{l}\text { MC3T3-E1, zirconia, } \\
\text { polycrystal }\end{array}$ & $2 \mu \mathrm{m}$ & - & - & $\begin{array}{l}\text { proliferation was significantly greater, The Runx } 2 \text { mRNA level increased time } \\
\text { dependently, calcification and ALP activity and osteocalcin mRNA levels were } \\
\text { higher }\end{array}$ \\
\hline $\begin{array}{l}\text { (Lu and Leng } \\
\text { 2009) [21] }\end{array}$ & $\begin{array}{l}\text { osteoblast, myoblast, } \\
\text { silicon }\end{array}$ & 8,24 & - & $2,4,10$ & $\begin{array}{l}8 \mu \mathrm{m} \text { width strongly affect both osteoblasts and myoblasts } 24 \mu \mathrm{m} \text { strongly affect } \\
\text { myoblasts only }\end{array}$ \\
\hline $\begin{array}{l}\text { (Lu and Leng } \\
\text { 2003) [40] }\end{array}$ & $\begin{array}{l}\text { osteoblast, myoblast, } \\
\text { silicon }\end{array}$ & 8,24 & - & $2,4,10$ & $\begin{array}{l}8 \mu \mathrm{m} \text { width strongly affect both osteoblasts and myoblasts, } 24 \mu \mathrm{m} \text { strongly affect } \\
\text { myoblasts only }\end{array}$ \\
\hline $\begin{array}{l}\text { (Lu and Leng } \\
2003)[40]\end{array}$ & $\mathrm{SaOS}-2$, Ti and HA & $4,8,16,24,30,38$ & - & $2,4,10$ & No difference in orientation angle between HA and Ti microgrooves \\
\hline $\begin{array}{l}\text { (Koo et al. 2014) } \\
{[41]}\end{array}$ & $\begin{array}{l}\text { human primary cells, } \\
\text { titanium }\end{array}$ & $15-, 30-, 60-$ & - & $3.5-, 10-$ & $\begin{array}{l}\text { lower levels of type I collagen } \alpha 1 \text { gene expression at day } 14 \text {, extremely increase } \\
\text { in osteopontin gene expression at days } 21 \text { and } 28\end{array}$ \\
\hline $\begin{array}{l}\text { (Hamilton and } \\
\text { Brunette 2007) [42] }\end{array}$ & $\begin{array}{l}\text { Osteoblast cell, epoxy- } \\
\text { resin }\end{array}$ & Pitch: $30-175$ & $5-175$ & & $\begin{array}{l}\text { Total tyrosine phosphorylation increased Src levels decrease, but FAK and } \\
\text { ERK1/2 phosphorylation were highest, Inhibition of Src phosphorylation with } \\
\text { PP2 inhibited FAK and ERK } 1 / 2 \text { phosphorylation }\end{array}$ \\
\hline $\begin{array}{l}\text { (Fransiska et al. } \\
\text { 2013) [43] }\end{array}$ & ROS, silicon & from 1 to 20 & - & - & $\begin{array}{l}\text { width less than } 10 \mu \mathrm{m} \text { induced the alignment of osteoblasts, increase osteogenic } \\
\text { proteins }\end{array}$ \\
\hline
\end{tabular}


Table 2. The influence of nanoscale microgrooves on osteoblasts' function.

\begin{tabular}{|c|c|c|c|c|c|}
\hline References & Cell and Substrate type & Groov width(nm) & Ridge width (nm) & $\begin{array}{l}\text { Groove Depth } \\
(\mathbf{n m})\end{array}$ & Results \\
\hline $\begin{array}{l}\text { (Lamers et al. } \\
\text { 2010) [25] }\end{array}$ & $\begin{array}{l}\text { rats bone marrow stromal } \\
\text { cells, silicon }\end{array}$ & down to 75 & - & down to 33 & $\begin{array}{l}\text { minimal align dimensions' width: } 75 \mathrm{~nm} \text { nanogroove-to-ridge ratios of } 1: 1 \text {, } \\
\text { 1:3 and } 3: 1 \text { depth:33nm. minimal mineralization width: } 50 \mathrm{~nm} \text {, depth:17nm, } \\
\text { osteoblast- specific gene expression increased }\end{array}$ \\
\hline $\begin{array}{l}\text { (Yim et al. } \\
2007)[44]\end{array}$ & $\begin{array}{l}\text { hMSCs, } \\
\text { Poly(dimethylsiloxane) }\end{array}$ & 350,700 & - & 350 & $\begin{array}{l}\text { Upregulation of neuronal } \\
\text { markers-MAP2 and GFAP }\end{array}$ \\
\hline $\begin{array}{l}\text { (Yang et al. } \\
2009)[45]\end{array}$ & MG-63, Silicon & $90,150,250,340,500$ & $90,150,250,340,500$ & - & elongated and aligned along the direction, so does cell nucleiei \\
\hline $\begin{array}{l}\text { (Abagnale } \text { et } \\
\text { al. 2015) [30] }\end{array}$ & MSCs, Polyimide & pitch of 650 & 200 & - & increased differentiation towards both osteogenic and adipogenic lineages \\
\hline $\begin{array}{l}\text { (Azeem et al. } \\
2015)[32]\end{array}$ & $\begin{array}{l}\text { Primary human osteoblasts } \\
\text { polystyrene }\end{array}$ & $\sim 1860$ & $\sim 2220$ & $\sim 35,306,2046$ & $\begin{array}{l}\sim 306 \text { and } 2046 \mathrm{~nm} \text { promote osteoblast alignment parallel to } \\
\text { underlined topography in vitro In vivo showed osteogenic ability }\end{array}$ \\
\hline $\begin{array}{l}\text { (Lenhert et al. } \\
\text { 2005) [46] }\end{array}$ & $\begin{array}{l}\text { Primary osteoblasts, } \\
\text { polystyrene }\end{array}$ & periodicity of 500 & 50,150 & - & align, elongate and migrate parallel to the grooves \\
\hline $\begin{array}{l}\text { (Lamers et al. } \\
\text { 2012) [47] }\end{array}$ & $\begin{array}{l}\text { old male Wistar WU rats } \\
\text { Osteoblast-like cells, silicon }\end{array}$ & periods $1000,300,150$ & $32-150$ & - & $\begin{array}{l}\text { Cells aligned down to } 300 \mathrm{~nm} \text { pitch In vivo } 150 \mathrm{~nm} \text { pitch grooves has the lowest } \\
\text { density of multinucleated cells }\end{array}$ \\
\hline $\begin{array}{l}\text { (Prodanov et } \\
\text { al. 2013) [48] }\end{array}$ & MC3T3-E1, silicon & 200 & - & 50 & $\begin{array}{l}\text { PFF (pulsatile fluid flow) did affect cellular morphology. Cells aligned on } \\
\text { nanotexture substrate in a direction parallel to the groove orientation }\end{array}$ \\
\hline $\begin{array}{l}\text { (Prodanov } \text { et } \\
\text { al. 2010) [49] }\end{array}$ & Rat MSCs, Silicone rubber & 300 (600 pitch) & $1 \mu \mathrm{m}($ pitch $2 \mu \mathrm{m})$ & $\sim 150,500$ & $\begin{array}{l}\text { perpendicular the substrates when parallel stretch to the nanotexture greater } \\
\text { than } 3 \% \text { applied }\end{array}$ \\
\hline $\begin{array}{l}\text { (Klymov et al. } \\
\text { 2015) [33] }\end{array}$ & $\begin{array}{l}\text { Rat MSCs, Silicon, } \\
\text { polystyrene }\end{array}$ & $\begin{array}{l}10-1000 \text { ridge to } \\
\text { groove ratios of } 1: 1 \\
1: 3 \text { and } 3: 1\end{array}$ & - & - & $\begin{array}{l}\text { All sizes of squares showed strong cell-repelling capacity. 3:1 partially } \\
\text { showed cell attraction }\end{array}$ \\
\hline
\end{tabular}

of the wettability and inclination of ridge. Soluble biochemical cues, dynamic control and regulation of topographical features, as well as cell co-culture systems, have all been declared to act in synergy with physical cues in regulating stem cell fate [38]. When we design a test, multi-factors should be taken into consideration. In conclusion, critical dimensions do play a part in regulating celluar behavior. However, it is a pity that we have not completely revealed the mystery of micronanotopographical on the osteoblasts. In addition, which dimension of microarrays is optimal for the adhesion, proliferation, differentiation, and osteogenisis is still under research. We can use the obtained data as a guide and reference for the study in the future. Besides, these results could be helpful in the design and fabrication of implants and biomaterials.

\section{Acknowledgement}

- The authors acknowledge funding from the Chengdu science and technology huimin engineering projects. China. 0040305301462. The authors declare no potential conflicts of interest with respect to the authorship and/or publication of this article.

\section{References}

1. Harrison RG (1911) On the stereotropism of embryonic cells. Science 34: 279-281. [Crossref]

2. Weiss P (1945) Experiments on cell and axon orientation in vitro: the role of colloidal exudates in tissue organization. J Exp Zoology 100: 353-386.

3. Rovensky YA, Slavnaja IL, Vasiliev JM (1971) Behaviour of fibroblast-like cells on grooved surfaces. Exp Cell Res 65: 193-201. [Crossref]

4. Meyle J, Wolburg H, von Recum AF (1993) Surface micromorphology and cellular interactions. J Biomater Appl 7: 362-374. [Crossref]

5. Von Recum A, Van Kooten T (1995) The influence of micro-topography on cellular response and the implications for silicone implants. J Biomater Sci 7: 181-198. [Crossref]

6. Biggs MJP, Richards RG, Dalby MJ (2010) Nanotopographical modification: a regulator of cellular function through focal adhesions. Nanomedicine 6: 619-633. [Crossref]

7. Vieu C, Carcenac F, Pepin A, Chen Y, Mejias M, et al. (2000) Electron beam lithography: resolution limits and applications. Appl Surf Sci 164: 111-117.

8. Delgado-Ruíz R, Calvo-Guirado J, Moreno P, Guardia J, Gomez-Moreno G, et al.
(2011) Femtosecond laser microstructuring of zirconia dental implants. $J$ Biomed Materials Res Part B: Applied Biomaterials 96: 91-100. [Crossref]

9. Delgado-Ruíz R, Gomez Moreno AG, Aguilar-Salvatierra A, Markovic A, MateSánchez JE, et al. (2015) Human fetal osteoblast behavior on zirconia dental implants and zirconia disks with microstructured surfaces. An experimental in vitro study. Clin Oral Implants Res. [Crossref]

10. Clark P, Connolly P, Curtis AS, Dow JA, Wilkinson CD (1991) Cell guidance by ultrafine topography in vitro. $J$ Cell Sci 99 : 73-77. [Crossref]

11. Nikkhah M, Edalat F, Manoucheri S, Khademhosseini A (2012) Engineering microscale topographies to control the cell-substrate interface. Biomaterials 33: 52305246. [Crossref]

12. Khademhosseini A, Langer R, Borenstein J, Vacanti JP (2006) Microscale technologies for tissue engineering and biology. Proceedings of the National Academy of Sciences of the United States of America. 103: 2480-2487. [Crossref]

13. Ricci JL, Alexander H (2001). Laser microtexturing of implant surfaces for enhanced tissue integration. Key Engineering Materials. Trans Tech Publ.

14. Delgado-Ruiz RA, Abboud M, Romanos G, Aguilar-Salvatierra A, Gomez-Moreno $\mathrm{G}$ (2014) Peri-implant bone organization surrounding zirconia-microgrooved surfaces circularly polarized light and confocal laser scanning microscopy study. Clin Oral Implants Res.

15. Wood M (2007) Colloidal lithography and current fabrication techniques producing in-plane nanotopography for biological applications. J Royal Society Interface 4: 1-17. [Crossref]

16. Yamano SA, Ma RM, Shanti SW, Kim K. Wada,C, et al..(2010) The influence of different implant materials on human gingival fibroblast morphology, proliferation, and gene expression. The Int J oral maxillofacial implants 26: 1247-1255.

17. Engler AJ, Sen S, Sweeney HL, Discher DE (2006) Matrix elasticity directs stem cell lineage specification. Cell 126: 677-689. [Crossref]

18. Schellenberg, A, S. Joussen, K. Moser, N. Hampe, N. Hersch, et al. (2014) Matrix elasticity, replicative senescence and DNA methylation patterns of mesenchymal stem cells. Biomaterials 35: 6351-6358. [Crossref]

19. Dunn GA, Heath JP (1976) A new hypothesis of contact guidance in tissue cells. Exp Cell Res 101: 1-14. [Crossref]

20. Dalby.M, M. Riehle, H. Johnstone, S. Affrossman, A.Curtis (2004) Investigating the limits of filopodial sensing: a brief report using SEM to image the interaction between $10 \mathrm{~nm}$ high nano-topography and fibroblast filopodia. Cell biology international 28: 229-236. [Crossref]

21. Lu.X, Y.Leng (2009) Comparison of the osteoblast and myoblast behavior on hydroxyapatite microgrooves. Journal of Biomedical Materials Research Part B Applied Biomaterials 90: 438-445 
22. Clark P, Connolly P, Curtis AS, Dow JA, Wilkinson CD (1987) Topographical control of cell behaviour. I. Simple step cues. Development 99: 439-448. [Crossref]

23. Biggs M, R. Richards, S. McFarlane, C. Wilkinson, R. Oreffo,M. (2008) Adhesion formation of primary human osteoblasts and the functional response of mesenchymal stem cells to $330 \mathrm{~nm}$ deep microgrooves. Journal of the Royal Society Interface 5: 1231-1242. [Crossref]

24. Calvo-Guirado J. L, A. Aguilar-Salvatierra, R. A. Delgado-Ruiz, B. Negri, M P. R. Fernández, et al. (2015) Histological and histomorphometric evaluation of zirconia dental implants modified by femtosecond laser versus titanium implants: an experimental study in fox hound dogs. Clinical implant dentistry and related research 17: 525-532.

25. Lamers E, X.F. Walboomers, M. Domanski, J. te Riet, F. C. van Delft, et al. (2010) The influence of nanoscale grooved substrates on osteoblast behavior and extracellular matrix deposition. Biomaterials 31: 3307-3316. [Crossref]

26. Puckett S, R. Pareta, T. J.Webster (2008). Nano rough micron patterned titanium for directing osteoblast morphology and adhesion. International journal of nanomedicine 3: 229-241. [Crossref]

27. Matsuzaka K, Walboomers XF, Yoshinari M, Inoue T, Jansen JA (2003) The attachment and growth behavior of osteoblast-like cells on microtextured surfaces. Biomaterials 24: 2711-2719. [Crossref]

28. Taniguchi Y, K. Kakura, K. Yamamoto, H. Kido,J. Yamazaki (2015) Accelerated Osteogenic Differentiation and Bone Formation on Zirconia with Surface Grooves Created with Fiber Laser Irradiation. Clinical implant dentistry and related research.

29. Ismail FS, Rohanizadeh R, Atwa S, Mason RS, Ruys AJ, et al. (2007) The influence of surface chemistry and topography on the contact guidance of MG63 osteoblast cells. $J$ Mater Sci Mater Med 18: 705-714. [Crossref]

30. Abagnale G, M Steger, VH Nguyen, N Hersch, A Sechi, et al. (2015) Surface topography enhances differentiation of mesenchymal stem cells towards osteogenic and adipogenic lineages. Biomaterials. 61: 316-326. [Crossref]

31. Webster TJ, Ejiofor JU (2004) Increased osteoblast adhesion on nanophase metals: Ti, Ti6A14V, and CoCrMo. Biomaterials 25: 4731-4739. [Crossref]

32. Azeem A, English A, Kumar P, Satyam A, Biggs M, et al. (2015) The influence of anisotropic nano- to micro-topography on in vitro and in vivo osteogenesis. Nanomedicine (Lond) 10: 693-711. [Crossref]

33. Klymov A, EM Bronkhorst, J te Riet, JA Jansen, XF Walboomers (2015) Bone marrowderived mesenchymal cells feature selective migration behavior on submicro-and nanodimensional multi-patterned substrates. Acta biomaterialia. 16: 117-125. [Crossref]

34. Dunn, G.,A. Brown. (1986) Alignment of fibroblasts on grooved surfaces described by a simple geometric transformation. Journal of cell science 83: 313-340. [Crossref]

35. Ricci J, J Charvet, S Frenkel, R Chang, P Nadkarni, et al. (2000) Bone response to laser microtextured surfaces. Bone Engineering. 25: 1-11.
36. Delgado-Ruíz RA, A Markovic, LJ Calvo-Guirado, Z Lazic, A Piattelli, et al. (2014). Implant stability and marginal bone level of microgrooved zirconia dental implants: A 3-month experimental study on dogs. Vojnosanitetski pregled 71: 451-461.

37. Pecora GE, Ceccarelli R, Bonelli M, Alexander H, Ricci JL (2009) Clinical evaluation of laser microtexturing for soft tissue and bone attachment to dental implants. Implant Dent 18: 57-66. [Crossref]

38. Chen W, Shao Y, Li X, Zhao G, Fu J (2014) Nanotopographical Surfaces for Stem Cel Fate Control: Engineering Mechanobiology from the Bottom. Nano Today 9: 759-784. [Crossref]

39. Biggs MJ, Richards RG, Gadegaard N, Wilkinson CD, Oreffo RO, et al. (2009) The use of nanoscale topography to modulate the dynamics of adhesion formation in primary osteoblasts and ERK/MAPK signalling in STRO-1+ enriched skeletal stem cells. Biomaterials 30: 5094-5103. [Crossref]

40. Lu X, Leng Y (2003) Quantitative analysis of osteoblast behavior on microgrooved hydroxyapatite and titanium substrata. J Biomed Mater Res Part A 66: 677-687.

41. Koo KT, Lee SW, Lee MH, Kim KH, Jung SH, et al. (2014) Time-dependent expression of osteoblast marker genes in human primary cells cultured on microgrooved titanium substrata. Clin oral Implants Res 25: 714-722. [Crossref]

42. Hamilton DW, Brunette DM (2007) The effect of substratum topography on osteoblast adhesion mediated signal transduction and phosphorylation. Biomaterials 28: 18061819.

43. Fransiska, S, Ho MH, Li CH, Shih JL, Hsiao SW, Thien SDV (2013) To enhance protein production from osteoblasts by using micro-patterned surfaces. Biochem Engg J 78: $120-127$.

44. Yim EK, Pang SW, Leong KW (2007) Synthetic nanostructures inducing differentiation of human mesenchymal stem cells into neuronal lineage. Exp Cell Res 313: 1820-1829. [Crossref]

45. Yang JY, Ting YC, Lai JY, Liu HL, Fang HW, et al. (2009) Quantitative analysis of osteoblast-like cells (MG63) morphology on nanogrooved substrata with various groove and ridge dimensions. J Biomed Mater Res A 90: 629-640. [Crossref]

46. Lenhert S, Meier MB, Meyer U, Chi L, Wiesmann HP (2005) Osteoblast alignment, elongation and migration on grooved polystyrene surfaces patterned by LangmuirBlodgett lithography. Biomaterials 26: 563-570. [Crossref]

47. Lamers E, Walboomers XF, Domanski M, Prodanov L, Melis J (2012) In vitro and in vivo evaluation of the inflammatory response to nanoscale grooved substrates. Nanomedicine 8: 308-317. [Crossref]

48. Prodanov L, Semeins CM, van Loon JJ, te Riet J, Jansen JA, et al. (2013) Influence of nanostructural environment and fluid flow on osteoblast-like cell behavior: a model for cell-mechanics studies. Acta Biomater 9: 6653-6662. [Crossref]

49. Prodanov L, te Riet J, Lamers E, Domanski M, Luttge R, et al. (2010) The interaction between nanoscale surface features and mechanical loading and its effect on osteoblastlike cells behavior. Biomaterials 31: 7758-7765. [Crossref]

Copyright: (C2016 Li Q. This is an open-access article distributed under the terms of the Creative Commons Attribution License, which permits unrestricted use, distribution, and reproduction in any medium, provided the original author and source are credited. 